\title{
Transformation processes of the city center of Budapest: from historical development to the new economy
}

Transformation processes of the city center of Budapest: from historical development to the new economy

Procesos de transformación del centro de la ciudad de Budapest: del desarrollo histórico a la nueva economía Les processus de transformation du centre de la ville de Budapest : du developpement historique à la nouvelle économie Processos de transformação do centro da cidade de Budapeste: do desenvolvimento histórico à nova economia

Péter Baji, Márton Berki and Éva Izsák

\section{(2) OpenEdition}

\section{Journals}

Electronic version

URL: http://journals.openedition.org/espacoeconomia/5049

DOI: $10.4000 /$ espacoeconomia.5049

ISSN: 2317-7837

\section{Publisher}

Núcleo de Pesquisa Espaço \& Economia

\section{Electronic reference}

Péter Baji, Márton Berki and Éva Izsák, "Transformation processes of the city center of Budapest from historical development to the new economy », Espaço e Economia [Online], 13 | 2018, Online since 21 December 2018, connection on 19 April 2019. URL : http://journals.openedition.org/ espacoeconomia/5049; DOI : 10.4000/espacoeconomia.5049

This text was automatically generated on 19 April 2019.

(C) NUPEE 


\title{
Transformation processes of the city center of Budapest: from historical development to the new economy
}

\author{
Transformation processes of the city center of Budapest: from historical \\ development to the new economy \\ Procesos de transformación del centro de la ciudad de Budapest: del desarrollo \\ histórico a la nueva economía \\ Les processus de transformation du centre de la ville de Budapest : du \\ developpement historique à la nouvelle économie \\ Processos de transformação do centro da cidade de Budapeste: do \\ desenvolvimento histórico à nova economia
}

Péter Baji, Márton Berki and Éva Izsák

In the case of Márton Berki, this work was completed in the ELTE Institutional Excellence Program (1783-3/2018/FEKUTSRAT), supported by the Hungarian Ministry of Human Capacities

\section{Introduction}

1 Over the past 25 years, Hungary witnessed elementary changes in almost all segments of life. On the one hand, there was a local politico-economic transition (from state socialism to market economy) starting from 1989-1990, moreover, parallel to that, several global political, economic and cultural processes also strongly influenced this specific local context (such as the restructuring of the Fordist, Keynesian welfare state into a postFordist, post-Keynesian neoliberal state). Importantly, these two levels of transition are mutually interrelated and interdependent, both strengthening and weakening each other (Sýkora, 2009). Therefore, albeit post-1990 changes might seem solely internal ones, they 
are in fact deeply embedded in contemporary processes of globalization. Since these changes are particularly rapid and intensive in metropolises (Stadelbauer, 2000; Burdack \& Herfert, 1998), especially in capital cities and their centrally located and functionally more saturated 'city' areas (Lichtenberger, 1995; Kluczka, 1996), the newly emerging spatial patterns evoked by these turbulent processes are in the forefront of urban geographical inquiry.

In the case of Central and Eastern Europe, the effects of the post-socialist transition and those of globalization have been investigated mostly from economic perspectives, for instance on the example of the housing market (among others, see the works of Kovács \& Wießner, 1995, 1997, 1999; Faßmann \& Lichtenberger, 1995; Faßmann, 1999). These analyses from the 1990s were mainly carried out on the (macro-)geographical scale of countries and their urban networks, thus, our knowledge on intra-urban spatial patterns remained somewhat insufficient (Keim, 2000). Although significant scholarly work has been done on Budapest in the same period (Berényi, 1994; Enyedi, 1999; Jungmann \& Szöcs, 2001; Izsák \& Probáld, 2001), however, only a few analyses focused on certain quarters - especially the 'city' - of the Hungarian capital; for some of these rare exceptions, see the seminal works of Lichtenberger (1995) and Kluczka (1996). Both investigations have shed light on the first signs of post-1990 city center transformations, including the spatio-temporal change of various functions or the spatial diffusion of 'city' functions (Lichtenberger, 1995).

With this paper, we aim at contributing to this body of literature by focusing on the 'city' of Budapest, one of the capital's most intriguing areas. First, a concise overview of the geographical notion of 'city' will be provided, after which the historical formation, evolution and transformation of Budapest's economic center will be presented. Second, the intricate relationship between the new economy and city centers will be outlined, followed by the presentation of the results of an empirical research focusing on the emergence and the spatiality of the new economy in the Hungarian capital's city center. We argue that in Budapest, just as in other European metropolises, the first apparent signs of economic changes are manifested in the 'city', and they diffuse from these central areas to other (inner) parts of the city.

\section{The notion of 'city' in European metropolises}

4 For around a century of urban structure analyses and other urban geographical investigations, a wide variety of terms have been used as the label of the central areas of cities, both in the international and in the Hungarian literature. In general, European urban geographical works often use the term 'city' in the case of the inner area of cities (e.g. City of London), whereas scholarly works focusing on the metropolises of other continents more likely use the term 'CBD' (central business district) in a similar although not completely identical or interchangeable - sense.

The etymology of the term 'city' might be traced back to two specific areas; one of these is the medieval city of London, while the other one is the royal and religious center of medieval Paris on the island of the Seine, referred to as the 'cité' (Tietze, 1968). Besides these, in the Middle Ages, the term 'city' was used more generally as well, for European towns that had a cathedral. Even though at that time the Ancient Latin word 'urbs' was also used for larger towns, however, eventually the term 'civis' (= burghers, urban 
citizens) became the root of all subsequent forms of 'city' (Online Etymology Dictionary, 2012). In the German context, it gradually turned into the term describing the center of cities, originally meaning their central quarters with the key institutions of governance, later also those of economic and cultural activities. After that, English episcopal towns were also labelled as 'cities' (Tietze, 1968), while in the wake of the European conquest and colonization of the Americas, 'city' became an internationally used notion, in contrast to the preceding term 'town' (thereafter used for population centers larger than villages but smaller than cities). In German geography, having been institutionalized in the second half of the $19^{\text {th }}$ century, as well as in the sub-discipline of urban geography unfolding in the early $20^{\text {th }}$ century, the command \& control center of metropolises was already labelled as 'city', even before the urban sociologists of the Chicago School started to popularize the notion of 'CBD' (Park \& Burgess, 1925).

6 Afterwards, starting from the 1950s, more and more nuanced definitions of the 'city' have been elaborated in German-speaking geography, with particular emphasis placed on the German understanding of the notion (see Tietze, 1968). In these views, 'city' was considered as the historical core of cities (being preserved since the Middle Ages) where local congregations had their large (museum-like) churches. Within the otherwise compact 'city' of Vienna, Austrian geographer Lichtenberger (1978) distinguished different non-profit command \& control centers such as the 'governance city' (existing since the $18^{\text {th }}$ century) or the 'university city'. In addition, Heineberg (2001) also noted that in the 'city' areas of large German cities, usually a lot of financial resources have been spent on representative buildings. Nonetheless, the economic character of the 'city' is very similar to that of the CBD: both terms denote inner city areas with a high concentration of banking, businesses, offices, administration, hotels and entertainment functions, while - according to Tietze (1968) - fashion industry, printing industry, publishing houses and medical specialist are also often found in the 'city'. Thus, besides their historical milieu, it is apparent that these centrally located areas of large European cities might also be considered as the spatial concentration of high-level tertiary (and later quaternary) functions. Here, agglomerations of company seats and company residences create various functional quarters, each of which is characterized by different development dynamics. Additionally, job density, store-window density, rental fees and land prices are very high in the 'city', and these areas are usually dotted with a great number of parking garages as well (Heineberg, 2001). As an important economic difference in contrast to the CBD, in European 'city' areas exclusive (and mostly very expensive) 'city-products' are being sold to high-income tourists visiting these quarters (Lichtenberger, 1978); therefore, here much larger emphasis is placed on historicalcultural traditions than in CBDs. Within the area of the typical European 'city', there is a high-quality shopping zone and several buildings of governance and administration, while a relatively small CBD can also be identified (Tietze, 1968). In accord with all the above considerations, it is obvious that in the Central and Eastern European historical context (primarily building on German geography), a clear distinction has to be drawn between the notions of 'city' and 'CBD'. The most converging understanding of the two terms can be found in the work of Heineberg (2001): on the one hand, he concludes that the extraordinarily high daytime and the relatively low nighttime population density is a common feature of the 'city' and CBDs, however, on the other hand he also points out that the residential population of the European metropolises' 'city' areas is constantly decreasing since the $19^{\text {th }}$ century, whereas North American CBDs are not characterized by this process. To recapitulate, the term 'city' denotes a broader notion than CBD, as it is 
not solely restricted to the spatial concentration of profit-oriented institutions but cultural functions are also of key importance in these areas (Brunotte, Gebhardt, Meurer, Meusburger \& Nipper, 2001).

\section{The boundaries of Budapest's 'city' as the economic center}

\section{Budapest's 'city' before the politico-economic transition}

7 Already in the beginning of the $20^{\text {th }}$ century, the 'city' area of Budapest was the capital's economic center. By then, while the political leadership of the Austro-Hungarian Empire established a 'governance city' in the (then) District IV, an 'economic city' also gradually evolved north of this area, in the (then) District V (Haltenberger, 1942). At that time, District IV was the historical core of the Pest side, originally being surrounded by city walls in the Middle Ages, with only some smaller sections of these fortifications surviving until the early $20^{\text {th }}$ century. The area was characterized by a vibrant scientific and social life, as well as by a great number of merchants.

8 North of this medieval core, in contrast, the (then) District V was a sandy and swampy area: hence, owing to the limited opportunities for agricultural production, mainly craftsmen and merchants started to settle here (Haltenberger, 1942). Starting from the 18 th century, however, the area has undergone a remarkably rapid development, since the inner city (District IV) became unable to accommodate the constantly increasing crowds attending its fairs. By the turn of the $19^{\text {th }}$ and $20^{\text {th }}$ centuries, this newly established center already had a stock exchange, business houses, and headquarters of the largest companies, moreover, the Hungarian Parliament and other governmental institutions were also built here. As another notable specificity of the area, the newly constructed 4-6 story buildings were the highest in Budapest at that time, thus, District V was soon towering above District IV. Furthermore, urban geographical analyses carried out before the 1950s also revealed that population density was on the decrease in both districts, partly because instead of homes, high-quality retail started to dominate up to the first floor of the buildings (Bulla \& Mendöl, 1947). To sum up, before World War II, Budapest's 'city' consisted of a southern cultural and a flourishing northern economic district (Figure 1). 
Figure 1: The districts of Budapest's 'city' in 1942

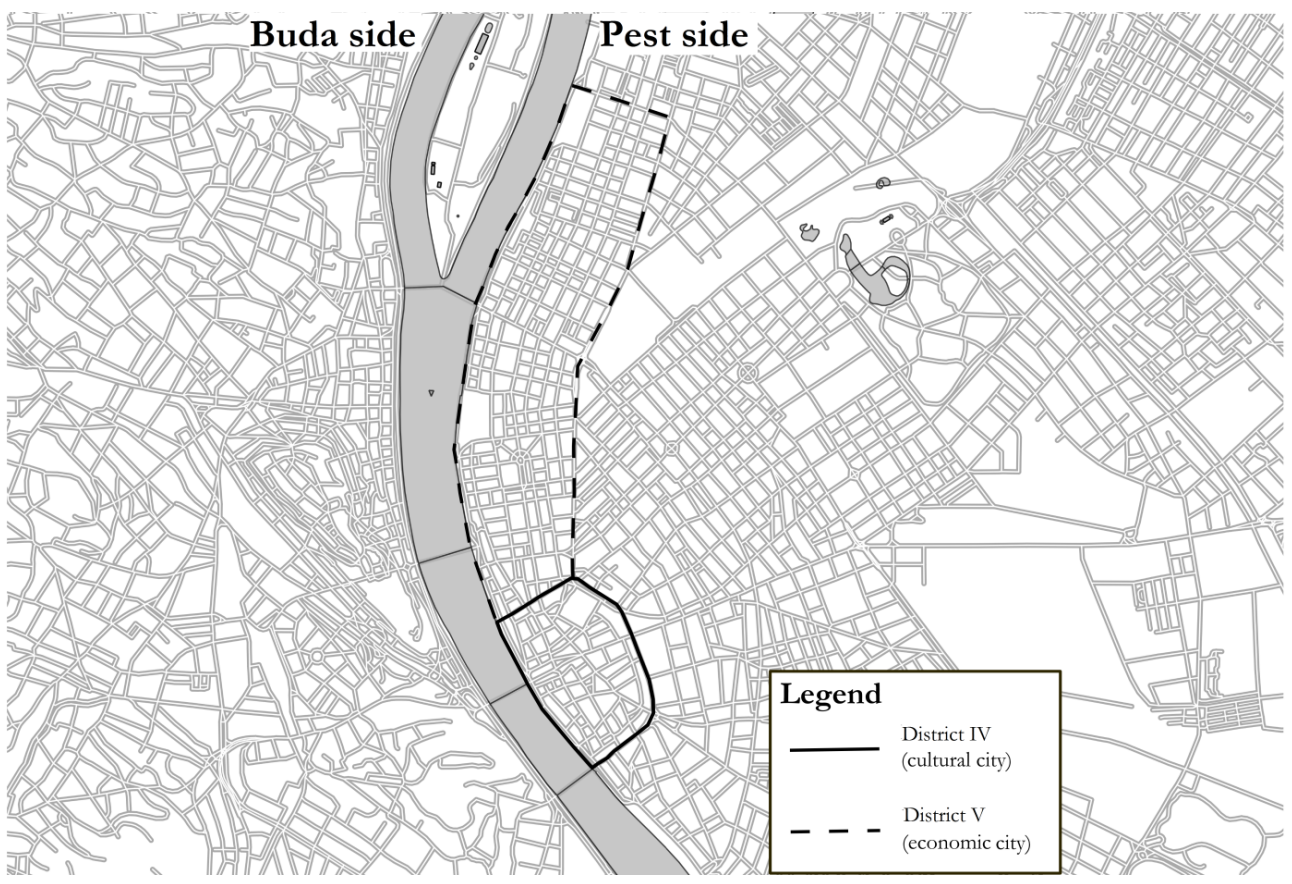

(SOURCE: DESIgNED BY THE AUTHORS)

After the war, the decades of state socialism caused fundamental changes in the entire Hungarian society and economy, significantly affecting the development of Budapest (and its 'city' area) as well. The overtly centralized urban policy of the newly settled socialist leadership concentrated on the (mass-)construction of housing estates on the fringe of the city on the one hand, and on the development of industrial areas on the other hand. Parallel to that, most inner city areas have been neglected for long decades, resulting in a process of gradual deterioration. At the same time, these areas were also treated as the hideout of the bourgeoisie, stigmatized as reactionists and considered as the enemies of the state. Therefore, in order to avoid capitalist-type residential segregation, their valuable pre-war housing stock was confiscated and then centrally reallocated (Kovács, 1992), primarily on the basis of political merits (such as party membership or political engagement). Since there was no need for a market-driven financial-commercial center in the capital city during this period, the development of Budapest's former 'city' area was stopped until the last years of state socialism, and the whole area remained no more than the country's political-administrative center.

\section{The development of Budapest's 'city' from 1990 to the present}

From the very beginning of the politico-economic transition, the Hungarian capital's economy started to operate under market conditions again, so that the pre-war process of 'city-formation' also continued (and intensified). By then, the former 'city' districts (IV and V) have been merged into a new District V (Figure 2), which - as the primary target and beneficiary of entrepreneurial capital (Beluszky, 1992) - began to develop tremendously. Owing to the massive influx of foreign direct investment and the construction of banks and office buildings during the 1990s, Budapest's 'economic city' slowly outgrew the boundaries of District V, and some authors predicted that it would 
soon expand to the entire Pest side inner city located within the Grand Boulevard (Kovács, 1993). In a stark contrast to these expectations, other researchers questioned whether Budapest has ever had a real 'city' (in the Western European sense of the term), since the Hungarian capital has undergone a remarkably different path of historical development compared to Western European metropolises - according to these views, if any similarities may be found, those would only be limited to District V (Lichtenberger, Cséfalvay \& Paal, 1995).

Figure 2: Borderlines of the 'economic city' of Budapest in the 1990s

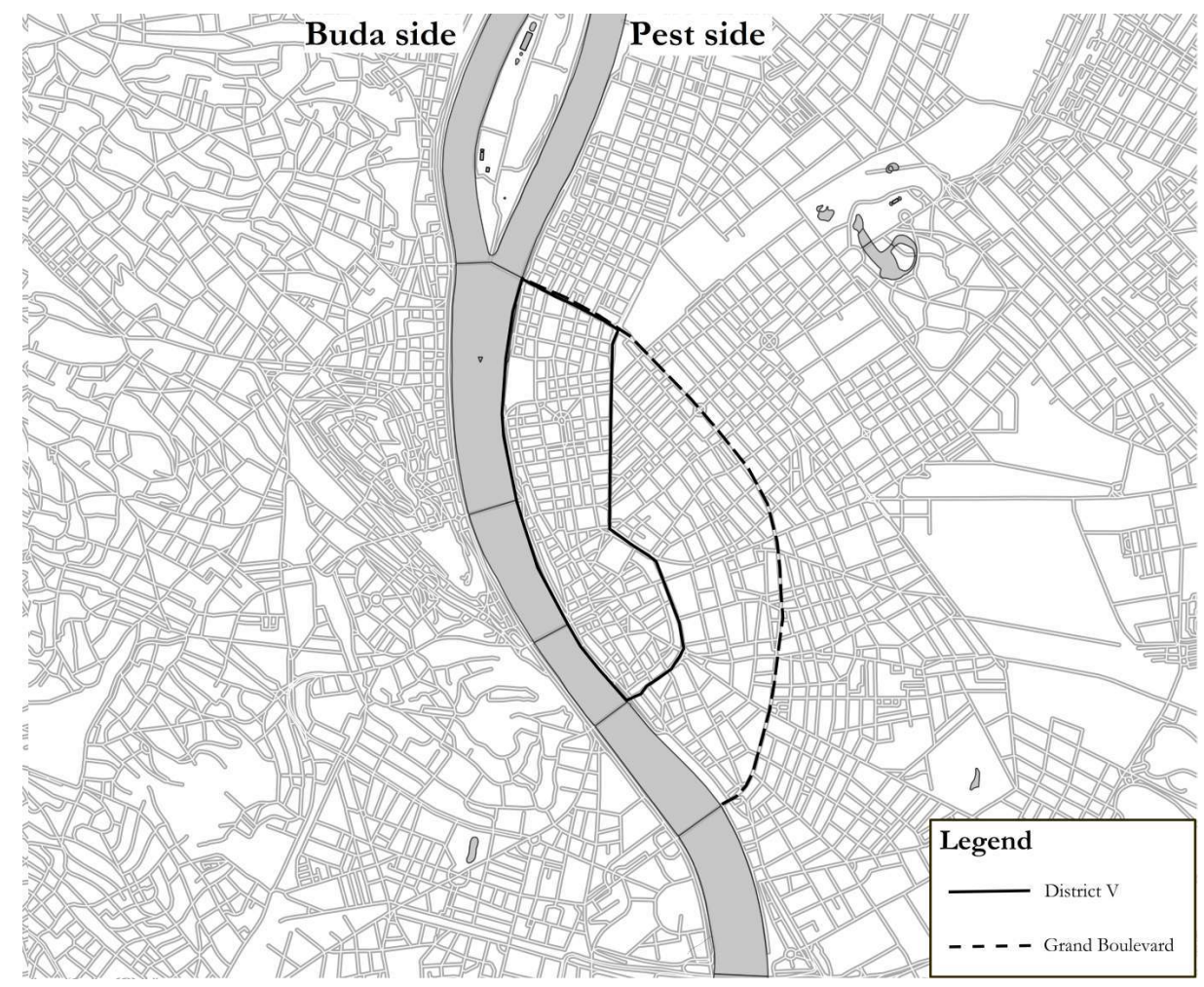

(SOURCE: DESIgNED BY THE AUTHORS)

In spite of these conceptual debates, it is evident that business and services functions considerably expanded in the inner city of Budapest during the 1990s (both quantitatively and geographically), and a growing number of former homes were turned into offices, in order to feed the increasing demand of companies willing to settle there. As a result, by the mid-2000s business function already dominated over residential function in the entire area between the Grand Boulevard and the Danube (Kovács, 2005). Interestingly, this initial spatial diffusion of 'city functions' was primarily horizontal: most companies used ground floor or first floor rooms as their offices, and when there was no more space available in the 'city', they started to search for places located farther from the capital's city center.

12 A comparative analysis of Berlin and Budapest, also carried out in the mid-2000s, identified new border points of Hungarian capital's 'city functions' (Figure 3). All of these points lay beyond the lines of the Grand Boulevard and the Danube, and they also denote specific growth axes along which business functions will most likely spread (Izsák \& Schulz, 2006). Moreover, two of these four border points are also special because they are located in Buda, challenging the long-standing view that the 'economic city' of Budapest 
was (and is) only forming on the Pest side. Therefore, although with a much lower intensity, the 'city' area of the capital is also growing on the Buda since the beginning of the post-socialist transition.

Figure 3: Border points and borderlines of the 'economic city' of Budapest after 2000

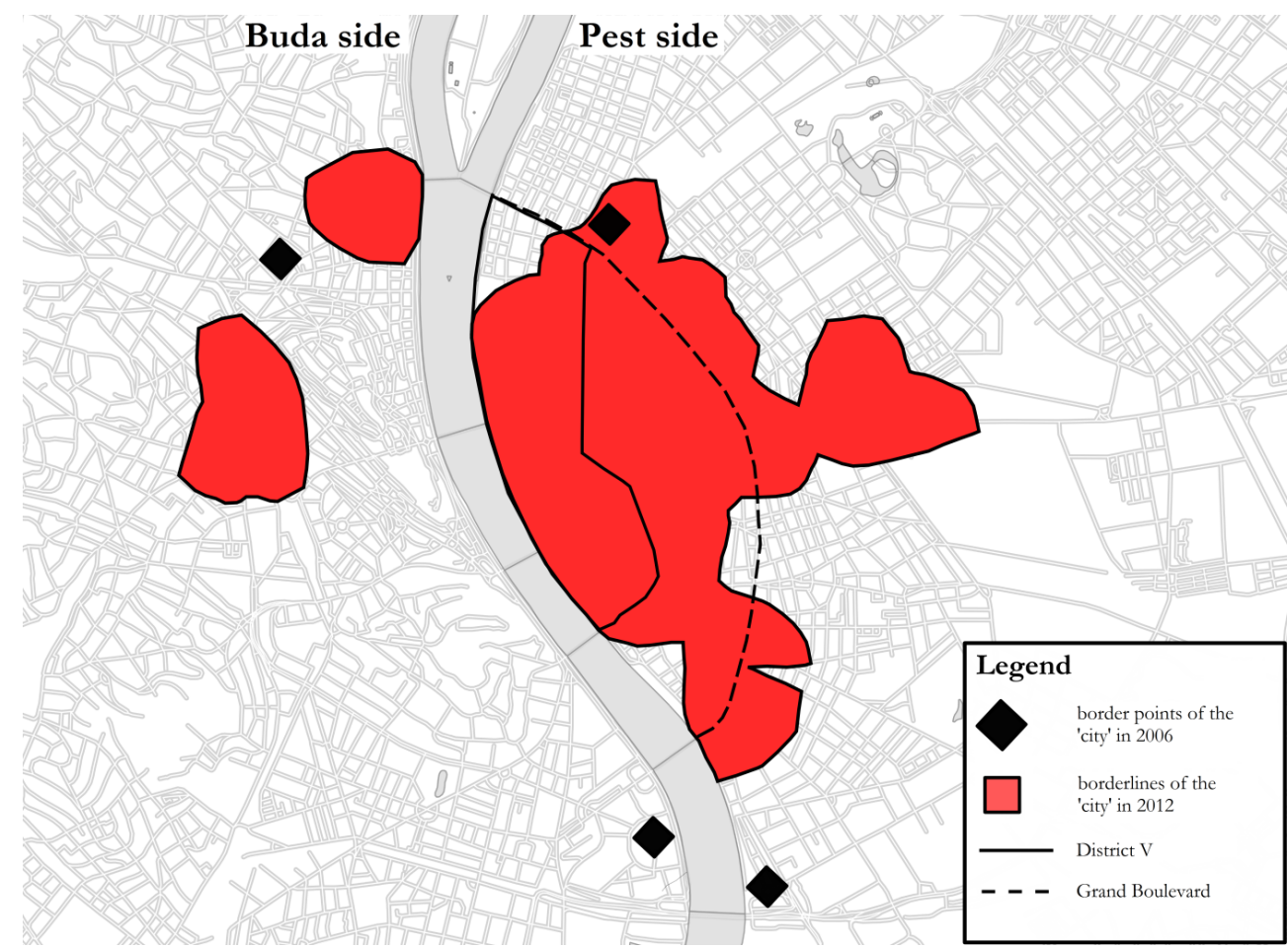

(Source: Izsák \& Schulz, 2006; Baji, 2012)

Building on the results of this 2006 comparative study, another analysis attempted to delimit the geographical extent of the 'economic city', both on the Pest side and the Buda side (Baji, 2012). This investigation focused on economic units that produce large profit, and hence, are able to operate their businesses in the capital's central areas characterized by high rental fees. A broad range of activities were taken into account, including those of companies aimed at fulfilling extraordinary consumer needs, since they have to be located in central areas in order to meet a large number of potential customers. Eventually three main types of activities were selected as indicators for drawing the boundaries of the 'economic city': banking, tourism, and the retail of special goods (e.g. wedding dresses, jewelry).

The main results of the research showed that over 20 years after the fall of state socialism the capital's 'economic city' stretched beyond the Grand Boulevard at several locations, yet this expansion followed an irregular pattern (Figure 3). In the Pest side, its northern part did not include the ministry quarter (in District V), however, it dynamically grew towards and beyond the capital's two main transportation hubs, Nyugati (Western) and Keleti (Eastern) railway stations. A similar kind of growth could be observed in its southern part as well, covering the rehabilitated areas of Ferencváros (District IX) and the so-called Corvin Quarter of Józsefváros (in District VIII). In both areas, large-scale urban regeneration projects have recently been carried out, which turned them into attractive locations for companies. Additionally, US-style shopping malls (WestEnd City Center, Arena Plaza, and Corvin Plaza) also played a key role in the formation and evolution of 
the 'economic city' in the Pest side, with a great number of companies settled in their immediate vicinity. Concerning the Buda side, 'economic city' formation could be traced in two areas. One of these was the neighborhood around Déli (Southern) railway station (Budapest's $3^{\text {rd }}$ largest railway station), while the other one was the area between Széll Kálmán Square and the Buda side bridgehead of Margaret Bridge. The latter was characterized by an exceptionally high concentration of specialized services (especially in and around the twin shopping malls of Mammut I and II), and therefore, could be considered as the extension of the Grand Boulevard on the Buda side.

To conclude, it is obvious that the 'economic city' of Budapest has undergone a dynamic development since the early 1990s, resulting in the massive spatial expansion of the related functions and activities. In the meantime, development cores emerged in the Buda side as well, albeit there is still much more space for such spatial diffusion in Pest, mostly due to topographical reasons. Around the Buda side patches of the 'economic city', mostly hilly terrains are found with upper class residential areas (characterized by the highest land prices of the entire capital city), whereas in the Pest side, residential function is more likely to turn into an economic one (owing to the better overall accessibility and connectivity of the area). Nevertheless, it is important to note that the boundaries demonstrated above reflect the 2012 conditions, yet that study might still shed light on the dynamically changing spatiality of economic actors, as well as on the constant fluctuation of these borderlines. After presenting a concise historical overview of the evolution (and the spatial expansion) of Budapest's 'city', we examine the emergence of the new economy in the Hungarian capital's city center.

\section{The emergence of the new economy in the 'city'}

\section{New economy and the city center}

16 In the contemporary international literature focusing on city centers, one of the recurring topics is the impact of the new economy on the transformation of the central parts of cities (Helbrecht, 1998; Indergaard, 2009; Barnes \& Hutton, 2009; Hutton, 2010; Zheng, 2011). The post-Fordist economic restructuring was accompanied by the closure of large factories located close to city centers on the hand, as well as by a dynamic change in the character of inner city districts on the other hand, both in North America and in Western Europe. With these transformations, according to Helbrecht (1998), broader societal changes are articulated in cities, since both modernism and postmodernism creates its specific urban forms. In accordance with this, under modern industrial capitalism large mono-functional areas (such as CBDs, industrial districts, or vast residential neighborhoods) were established, reflecting the need for order and uniformity. In contrast, cities of the postmodern age are characterized by rather fragmented, kaleidoscope-like spatial patterns, where the urban structure of classical urban ecology is gradually replaced by a consumption-driven city consisting of the collage of functionally heterogeneous parcels (Dear \& Flusty, 2002). The high-level fragmentation of urban functions is partly emerging due to the rise of the new economy, since the related firms and their employees often move to certain parts of centrally located working class districts, or to some of the similarly well-located former industrial areas. As a result, this specific form of gentrification may change the population of entire districts. It has been documented in several locations from around the world, for instance 
in the case of Liberty Village in Toronto (Catungal, Leslie \& Hii, 2009), in the Australian city of Wollongong (Waitt \& Gibson, 2009), or in Milan's Bicocca district (Sacco \& Blessi 2009).

Since market mechanisms were repressed in Hungary during the period of state socialism, and there was no space for demand-oriented production typical of the new economy, these transformation processes reached Budapest with a significant delay. Hungarian authors started to deal with the emergence of the new economy after the turn of the millennia, partly because the entire phenomenon only appeared in the country around that time (see Enyedi, 2002; Jakobi, 2007; Egedy \& Kovács, 2011). These pioneering works, however, mostly discussed the rise of the new economy either from a theoretical perspective, or on a national or regional scale. This created a significant research gap on smaller geographical scales (i.e. empirical studies on urban and intra-urban levels), resulting in a lack of knowledge on the spatiality of the new economy in the capital city. Therefore, with this study we attempt to fill this gap by searching for appropriate methods to explore the clusters of new economy in Budapest, as they have been explored in the case of several other cities (Hutton, 2008; Zheng, 2011).

\section{Database of the research}

In order to describe and empirically investigate the new economy, the related literature distinguishes between three main notions: (1) information economy, (2) creative economy, and (3) cultural economy (Baji, 2014). Information economy approaches the new economy mostly from the side of digital infrastructures, creative economy primarily concentrates on a newly emerged, specific social group (the typical workforce of the new economy), whereas in the case of cultural economy, the main emphasis is placed on the cultural and symbolic added value of various products. Most empirical analyses are focusing on activities which somehow combine these three large domains (see Scott, 1997; Helbrecht, 1998; Florida, 2005). Following this research tradition, in our investigation four groups of activities have been outlined that are covering overlapping intersections of the above-mentioned three main categories (Table 1). 
Table 1: Activities associated with the new economy

\begin{tabular}{|c|c|c|c|}
\hline $\begin{array}{l}\text { Information \& } \\
\text { creative \& cultural } \\
\text { economy }\end{array}$ & $\begin{array}{c}\text { Information } \& \\
\text { creative economy }\end{array}$ & $\begin{array}{l}\text { Information } \& \\
\text { cultural economy }\end{array}$ & $\begin{array}{l}\text { Creative \& cultural } \\
\text { economy }\end{array}$ \\
\hline $\begin{array}{l}58.21 \text { Computer } \\
\text { games publishing } \\
59.11 \text { Production of } \\
\text { movies, videos and } \\
\text { television programs } \\
59.20 \text { Audio } \\
\text { recording and } \\
\text { publishing } \\
60.10 \text { Radio } \\
\text { broadcasting } \\
60.20 \text { Television } \\
\text { program recording and } \\
\text { broadcasting } \\
63.91 \text { News agency } \\
\text { activities } \\
70.21 \text { PR and } \\
\text { communication } \\
72.20 \text { Social } \\
\text { sciences and human } \\
\text { research and } \\
\text { development } 73.11 \text { Advertising } \\
\text { agency activities } \\
73.12 \text { Media } \\
\text { advertising }\end{array}$ & $\begin{array}{l}58.29 \text { Other } \\
\text { software publishing } \\
62.01 \text { Computer } \\
\text { programming } \\
62.02 \text { Information } \\
\text { technology consulting } \\
72.11 \\
\text { Biotechnology and } \\
\text { research } \\
\text { development } \\
72.19 \text { Other natural } \\
\text { sciences research and } \\
\text { development } \\
73.20 \text { Market } \\
\text { research and public } \\
\text { opinion research }\end{array}$ & $\begin{array}{cr}58.11 & \text { Book } \\
\text { publishing } & \\
58.13 & \text { Daily } \\
\text { newspaper publishing } \\
58.14 & \text { Magazine } \\
\text { and } & \text { periodical } \\
\text { publishing } & \\
59.14 & \text { Movie } \\
\text { screening } & \end{array}$ & $\begin{array}{l}\text { 71.11 Architectural } \\
\text { activities } \\
74.10 \text { Fashion and } \\
\text { design }\end{array}$ \\
\hline
\end{tabular}

(SOURCE: COMPILED BY THE AUTHORS)

19 After defining the activities based on the occupational classification of the Hungarian Central Statistical office (HCSO), a database has been created in which firms were linked to the activities listed in Table 1. The business register of HCSO indexes enterprises according to their main activity, however, if companies in Hungary abandon their main business activity and only pursue any of their ancillary activities, they might be excluded from official statistics; therefore, we decided to build our own company database for the research.

Importantly, only firms were selected that are associated with any of the 22 types of activities, that have either company seat or company residence in Budapest, as well as have an Internet website positioned within the first 200 search results of 'google.hu'. Having company websites as one of the criteria for selection might be justified by the phenomenon known in the international economics literature as 'the economics of attention' (Szabó \& Hámori, 2006). According to this approach, the attention of customers seeking information on the Internet is finite, and due to the multitude of competing companies, only the ones can be competitive that are able to stay in the center of the web browsers' attention. Hence, companies whose websites are easy to find via search engines (e.g. Google) are more likely to succeed. The outstanding role of the Internet is especially true for companies of the new economy, since the vast majority of these firms operate in a completely online environment (such as in the case of web designing). Thus, as it was already forecasted by several economists since the 1990s, the real currency of the new economy is not money, but attention (Goldhaber, 1997): for today's companies, it is essential to achieve (and keep) top positions in the search engine results because customers only pay their attention to the first hits of these lists. 
21 As for search engines, Google has been chosen because it is undoubtedly the most widespread and popular one, moreover, Hungarian SEO (Search Engine Optimization) companies almost exclusively offer better search result rankings in Google for their clients. During the process of data mining, specific keywords were used that describe the given activity the best (e.g. 59.20 Audio recording - keyword: 'recording studio'). The reason for taking into account only the first 200 search results was the enormous volume of data on the one hand, and the consumers' otherwise limited capacity for processing information on the other hand. This data mining also enabled us to receive reliable information about the companies' real activities (being advertised on their websites), making sure that only the ones are included in the analysis which actually pursue a given activity. In addition, all selected companies have been checked on the tax number register website 'adoszam.hu' (whether they still exist or not), and only the currently existing ones were added to the database. This checking stage revealed that the official business register of HCSO is not always showing the companies' actual activities; for instance, a significant share of interior design firms that are normally associated with the statistical category ' 74.10 Fashion and design' are in fact registered under other categories (mostly '71.11 Architectural activities'). With all these experiences, our attempt to build our own database has been further justified.

Eventually the database consisted of 1.513 companies. As of the end of 2013, all of these pursued activities associated with the new economy, they actually existed, and maintained their own websites. $42 \%$ of the firms were simultaneously associated with the information, the creative, and the cultural economy, $26 \%$ with the information and the creative economy, $18 \%$ with the creative and the cultural economy, and $14 \%$ with the information and the cultural economy (Figure 4).

Figure 4: Distribution of new economy firms by overlapping categories

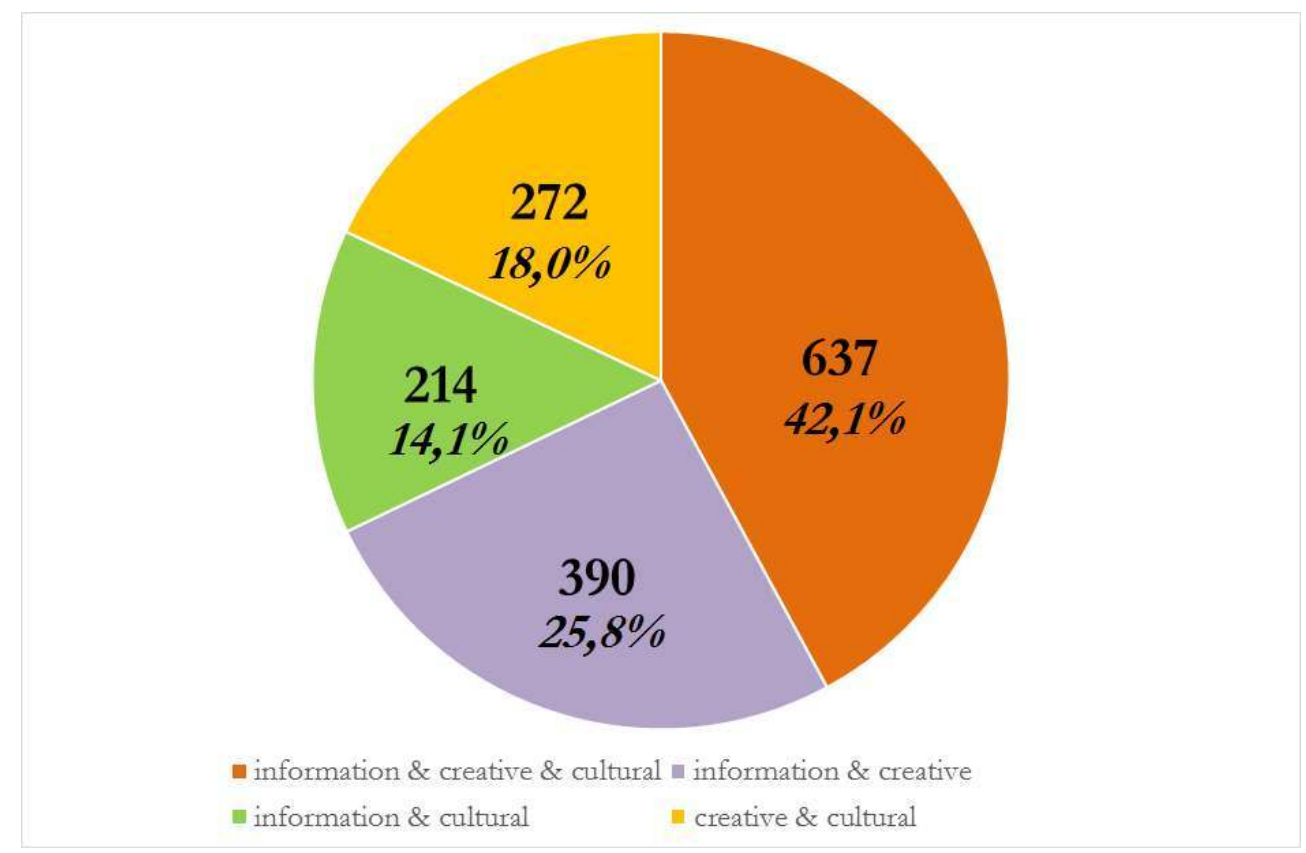

(DATA SOURCE: COMPILED BY THE AUTHORS)

Within the four large overlapping categories of the new economy, the number of companies associated with a given activity varies greatly (Figure 5). The majority of firms 
belonging to all three domains (information, creative, and cultural economy) are dealing with advertising agency activities (73.11), the production of movies, videos and television programs (59.11), as well as with PR and communication (70.21). Besides these, although to a lesser degree, the presence of firms associated with audio recording and publishing (59.20), television program recording and broadcasting (60.20), and radio broadcasting (60.10) is also notable. As for the intersection of the information and the creative economy, most companies are associated with computer programming (62.01) and other software publishing (58.29), followed by the ones into market research and public opinion research (73.20), and into other natural sciences research and development (72.19). Concerning the joint field of the information and the cultural economy, the most dominant activity is book publishing (58.11), along with a minor role of magazine and periodical publishing (58.14) and movie screening (59.14). Finally, within the overlapping domain of the creative and the cultural economy, most firms are associated with fashion and design (74.10), which is not surprising since costume design, interior design, graphic design and industrial design are all registered under this statistical category (followed by a considerable number of companies involved in architectural activities [71.11]).

Figure 5: Distribution of new economy firms by activities

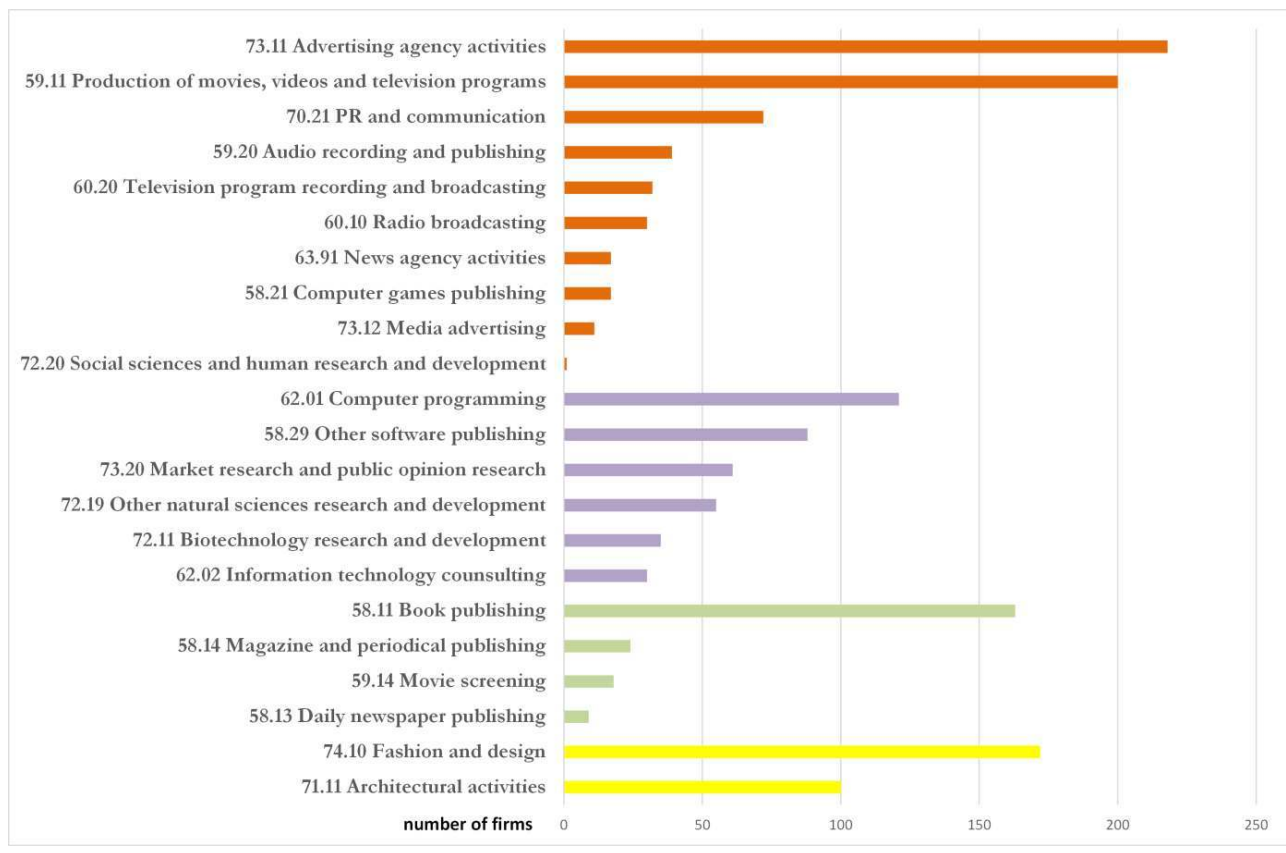

(Data source: compiled by the authors)

\section{The geographical patterns of new economy firms}

Based on their addresses, the locations of all 1.513 companies have been mapped (Figure 6), in order to analyze their spatial patterns and their strategies for finding seats or residences in Budapest. The vast majority of these firms are concentrated in the capital's inner city or in its close proximity, making these central areas still very attractive for enterprises, even more than 20 years after the beginning of the politico-economic transition. Besides these, several sub-centers emerged north of this core area as well, both on the Buda side (e.g. Graphisoft Park, located on the area of the former Óbuda Gasworks) and on the Pest side (in Zugló, with one of the oldest film studios of Budapest). 
In contrast, new economy firms are much more scattered in the southern and eastern parts of the capital city.

Figure 6: Geographical distribution of new economy firms in Budapest in 2013

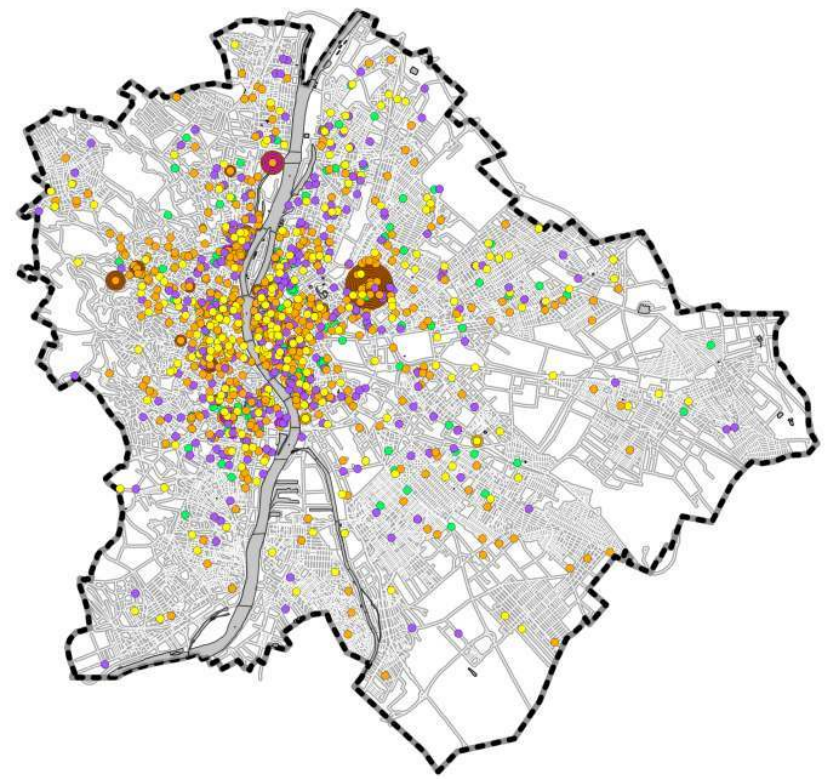

Legend

- Information \& creative \& cultural economy

- Information \& creative economy

Information \& cultural economy

Creative \& cultural economy

(DATA SOURCE: COMPILED BY THE AUTHORS)

In order to grasp the impact of new economy companies on the capital's urban morphology, 'clusters' of new economy have been delineated, representing spatial concentrations of firms in relatively small areas. The delineation of these clusters was carried out on the level of building blocks: only those blocks were considered as parts of a new economy cluster where at least 5 companies were located, both within the given block and/or in one of the physically adjacent blocks. Furthermore, building blocks are usually areas within a walking distance, providing firms with the opportunity for real cluster-like cooperation. The selected blocks (with at least 5-5 companies) were often physically connected to each other; hence, the clusters of new economy were formed out of the compact zones of these adjacent blocks.

As the outcome of the research, altogether 31 new economy clusters have been identified in Budapest (Figure 7), with the area of the three largest ones exceeding $1 \mathrm{~km}^{2}$. The largest contiguous cluster stretches between Margaret Bridge and Petöfi Bridge on the Pest side, and is entirely located within the capital's 'economic city' (visualized in Figure 3). This central one is surrounded by 11 smaller clusters that are also situated in the (broadly understood) city center. Owing to topographical reasons (a rather hilly terrain), no contiguous 'city' area could evolve in Buda over the $20^{\text {th }}$ century, thus new economy clusters are still more scattered here. However, somewhat surprisingly, the second and third largest concentrations of new economy companies are located on the Buda side, one of them around Szépvölgyi Str. (South óbuda), and the other one on the area behind the Buda Castle (MOM-Vérmezö). Besides these two large ones, another 7 clusters are 
situated in central Buda. Therefore, there is a total number of 21 new economy clusters in Budapest that are located either within the Pest side and Buda side 'economic city', or in their immediate vicinity. In terms of their area, these make up $84.5 \%$ of the delineated clusters. Consequently, the city center of Budapest is still very successful in attracting cutting edge companies and innovative modes of production.

Figure 7: Clusters of new economy in Budapest in 2013

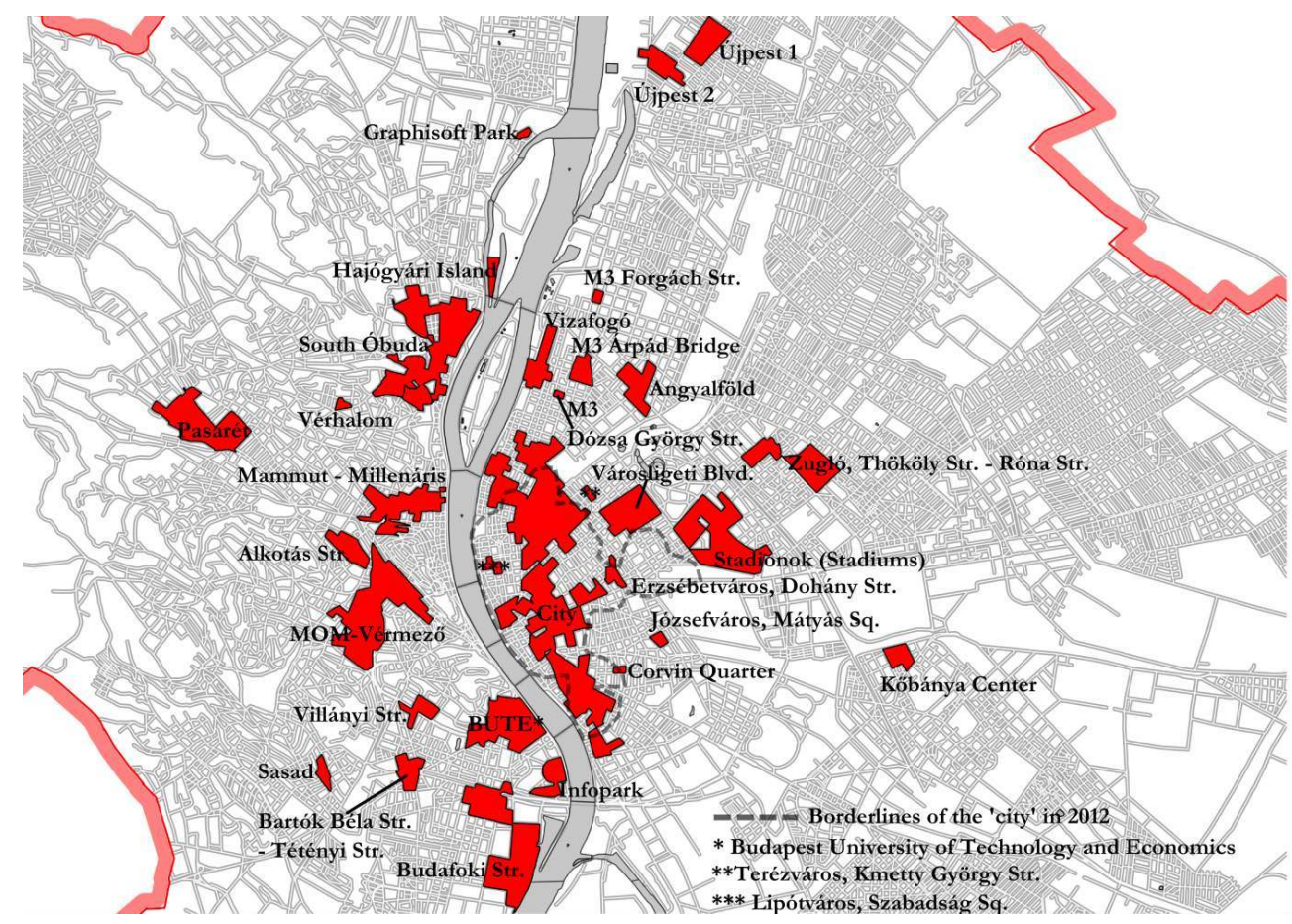

(DATA SOURCE: COMPILED BY THE AUTHORS)

\section{Processes of urban transformation within the clusters of new economy}

After the identification of new economy clusters, as a subsequent stage of the research, all of them have been examined on site. With this, we attempted to investigate different intensities of urban renewal in the areas where new economy companies are concentrated. All involved building blocks were classified based on the overall quality of their property stock, using the following categories: (1) good quality blocks (where less than $50 \%$ of properties require renovation), (2) medium quality blocks (with $50-75 \%$ of properties being in need of renovation), and finally, (3) bad quality building blocks (with this rate being over 75\%). Besides that, building blocks were also classified along the rate of renovated or refurbished properties (acquiring new functions) per $\mathrm{km}^{2}$, as well as along the rate of new apartment complexes (built after 2000) per $\mathrm{km}^{2}$. Based on these three sets of data, an index was created using the following method: the values of a given cluster were expressed as the average of the three data sets, and then the three values of each cluster were added together. With the help of this index, the dominant transformation processes of the clusters were rated on a three-point scale: (1) zero or low urban renewal rate, (2) medium urban renewal rate, and (3) high urban renewal rate. These data were then averaged for each cluster, and a crosstab was conducted (Table 2). 
Table 2: Clusters of new economy classified by the quality of buildings and the intensity of urban renewal processes in the city center of Budapest in 2013

\begin{tabular}{|c|c|c|c|}
\hline & \multicolumn{3}{|c|}{ Urban renewal processes } \\
\hline $\begin{array}{l}\text { Quality of } \\
\text { buildings }\end{array}$ & $\begin{array}{l}\text { Zero or low urban } \\
\text { renewal rate }\end{array}$ & Medium urban renewal rate & High urban renewal rate \\
\hline Good quality & $\begin{array}{l}\text { Bartók Béla Str.- } \\
\text { Tétényi Str. } \\
\text { Infopark } \\
\text { Villányi Str. }\end{array}$ & $\begin{array}{l}\text { MOM-Vérmező } \\
\text { BUTE (Budapest University of } \\
\text { Technology and Economics) } \\
\text { M3 Dózsa György Str. } \\
\text { Budafoki Str. }\end{array}$ & South óbuda \\
\hline $\begin{array}{l}\text { Medium } \\
\text { quality }\end{array}$ & - & $\begin{array}{l}\text { Alkotás Str. } \\
\text { Városligeti Blvd. }\end{array}$ & $\begin{array}{l}\text { Corvin Quarter } \\
\text { Terézváros, Kmetty } \\
\text { György Str. } \\
\text { Lipótváros, Szabadság } \\
\text { Sq. } \\
\text { Erzsébetváros, } \\
\text { Dohány Str. } \\
\text { Mammut-Millenáris } \\
\text { Vizafogó }\end{array}$ \\
\hline Bad quality & $\begin{array}{l}\text { Stadionok } \\
\text { (Stadiums) } \\
\text { Angyalföld } \\
\text { Józsefváros, Mátyás } \\
\text { Sq. }\end{array}$ & M3 Árpád Bridge & City \\
\hline
\end{tabular}

(DATA SOURCE: COMPILED BY THE AUTHORS)

Almost three-fourths of the 21 inner city clusters are characterized by medium or high urban renewal rate. Concerning the ones with a high rate, the most outstanding is South óbuda (Picture 1), where the excellent quality of the property stock is coupled with a constant construction of new offices and apartment complexes. This area contains a particularly dense concentration of companies associated with all three pillars of the new economy (information, creative, and cultural economy). 


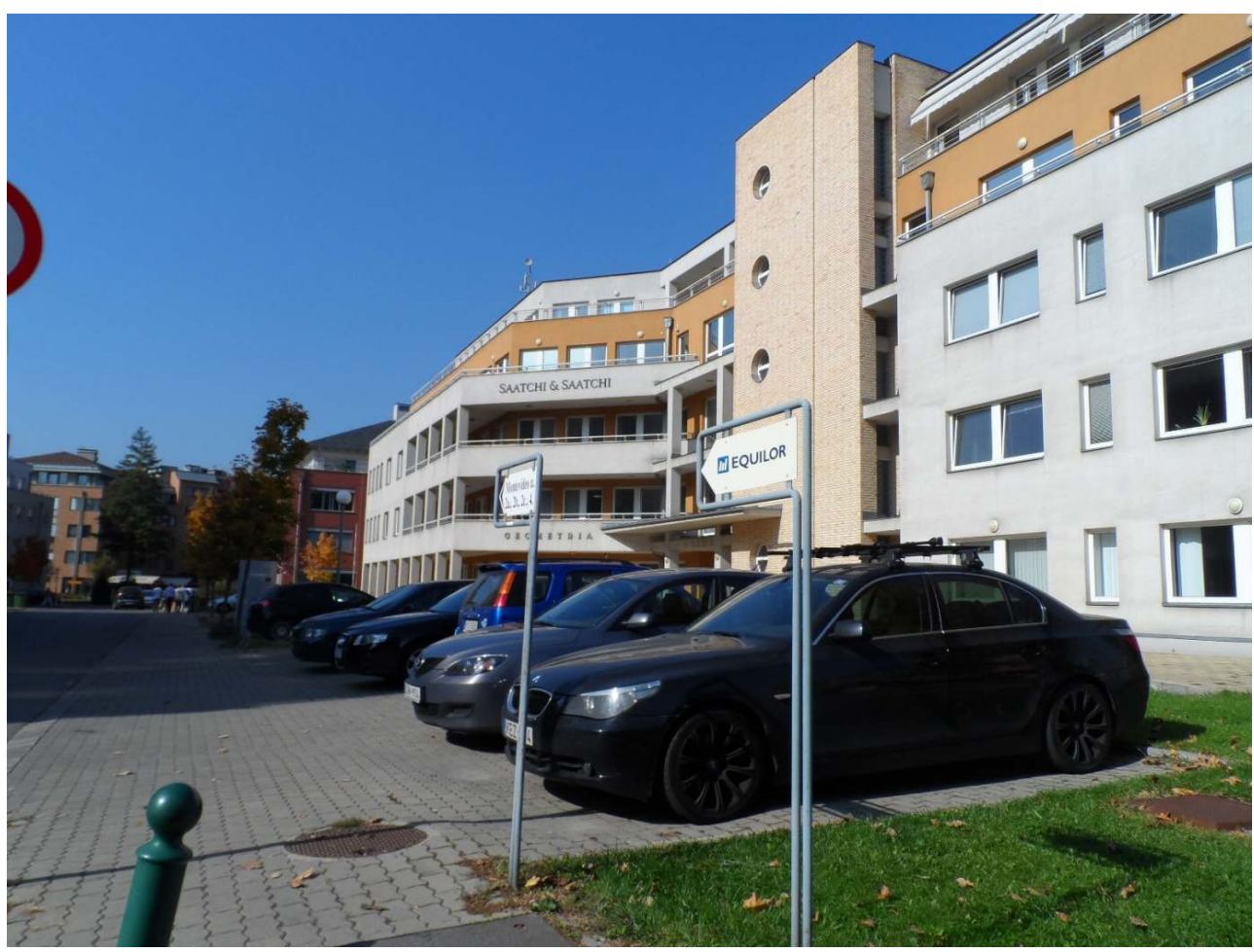

(SOURCE: PHOTOgRAPH TAKEN BY THE AUTHORS)

Also on the Buda side, a medium quality property stock was observed in the neighborhood around the twin shopping malls of Mammut I-II and the cultural-leisure venue of Millenáris (previously identified as one of the border points of Budapest's 'city'). During the last years, however, the most intensive urban renewal processes were/are taking place here, as well as in the smaller new economy clusters around the Pest side 'city' (also characterized by medium quality buildings). The worst quality property stock was registered within the Pest side 'city' itself, otherwise constituting the largest (and thus, the most heterogeneous) cluster with its sheer size being over $3 \mathrm{~km}^{2}$ (Picture 2). As noted earlier, this area was largely neglected during the socialist era, and although a multitude of investments have been made here over the past 20 years, the inner city's old (mostly $19^{\text {th }}$ century) property stock is renewed only very slowly. In spite of the ongoing investments, a significant share of new economy firms are still 'less visible' in this cluster (operating on upper floors of old inner courtyard tenement buildings). 


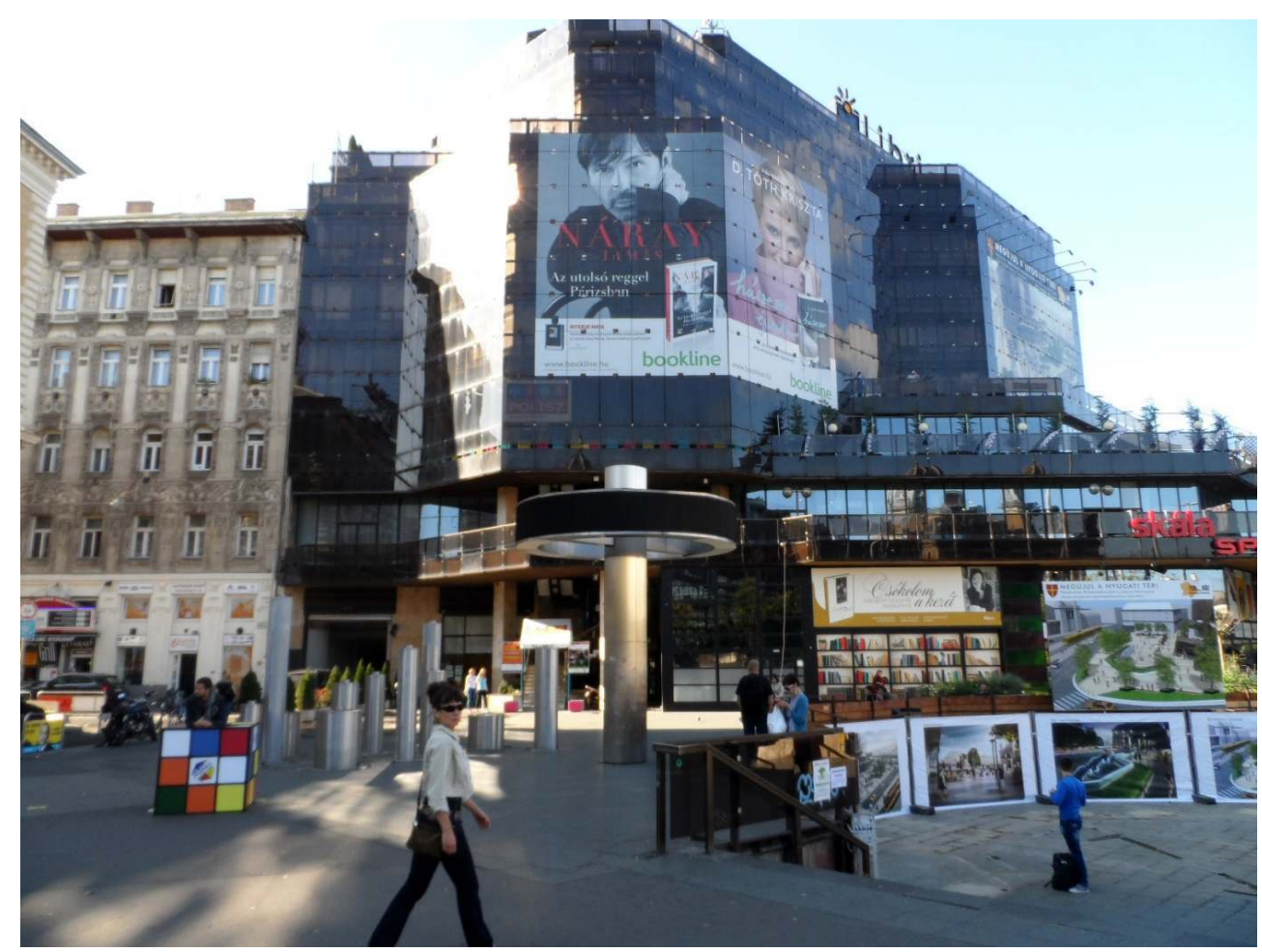

(SOURCE: PHOTOgRAPH TAKEN BY THE AUTHORS)

30 Concerning the clusters characterized by medium intensity urban renewal processes, three are located on the Pest side (M3 Árpád Bridge, M3 Dózsa György Street, Városligeti Boulevard). The quality of the property stock is the best around the Dózsa György Street station of Metro 3, whereas it is somewhat worse along Városligeti Boulevard, and especially around the Pest side bridgehead of Árpád Bridge (another station of Metro 3). In the vicinity of the two metro stations, enterprises associated with the information and the creative economy are the most dominant ones, however, in the case of all three clusters - similarly to those operating in the 'city' - companies are also less apparent.

31 On the Buda side, four new economy clusters are found in areas that are witnessing medium intensity urban renewal. Three of these, Budafoki Street, MOM-Vérmezo, and the main campus of BUTE (Budapest University of Technology and Economics) have excellent quality properties. Among them, the southern part of Budafoki Street is especially dotted with newly constructed offices and apartment complexes, therefore, urban transformations caused by the new economy are the most visible here (Picture 3). 


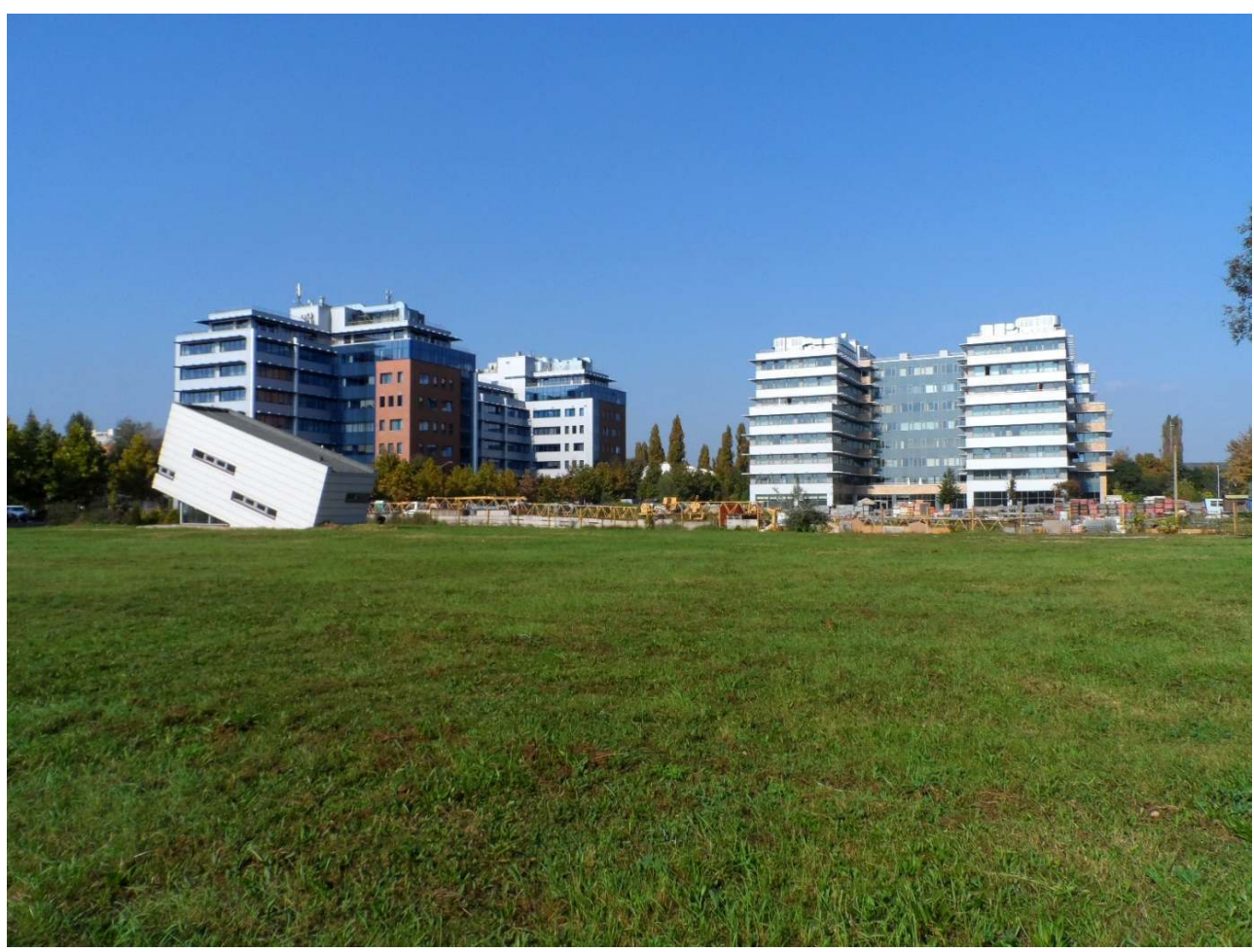

STREET (SOURCE: PHOTOgRAPH TAKEN BY THE AUTHORS)

32 Finally, only six of the examined new economy clusters have been left untouched by the process of urban renewal. At the same time, however, these are the areas that show the highest diversity. Three of these clusters are located on the Buda side, in neighborhoods with high quality property stock. Relatively loosely built residential areas are found around the junction of Bartók Béla Street and Tétényi Street, as well as in the cluster around Villányi Street, where the proximity of the Buda side inner city is still very attractive for companies. In contrast to these two older but well-preserved areas, the innovation and technology park called Infopark is a very recent development (hence requiring no renovation), which has primarily been established to provide information economy firms with appropriate seats and/or residences. In the case of all three clusters, creative companies dealing with informatics are overrepresented.

As a striking contrast, the three clusters on the Pest side are characterized by the worst built environment, with new economy firms also being 'less visible', hidden inside of older (mostly inner courtyard) buildings. Even though their property stock is physically deteriorated (Picture 4), the generally low rental fees and their location in the vicinity of the inner city make them a reasonable choice for enterprises dealing with one of the overlapping activities of the information, the creative, and the cultural economy. After Hutton's (2008) terminology, these clusters might be labelled as the sites of 'incipient new economy', and will presumably be characterized by pioneer gentrification in the near future. 
Picture 4: Deteriorated buildings near Stadionok (Stadiums)

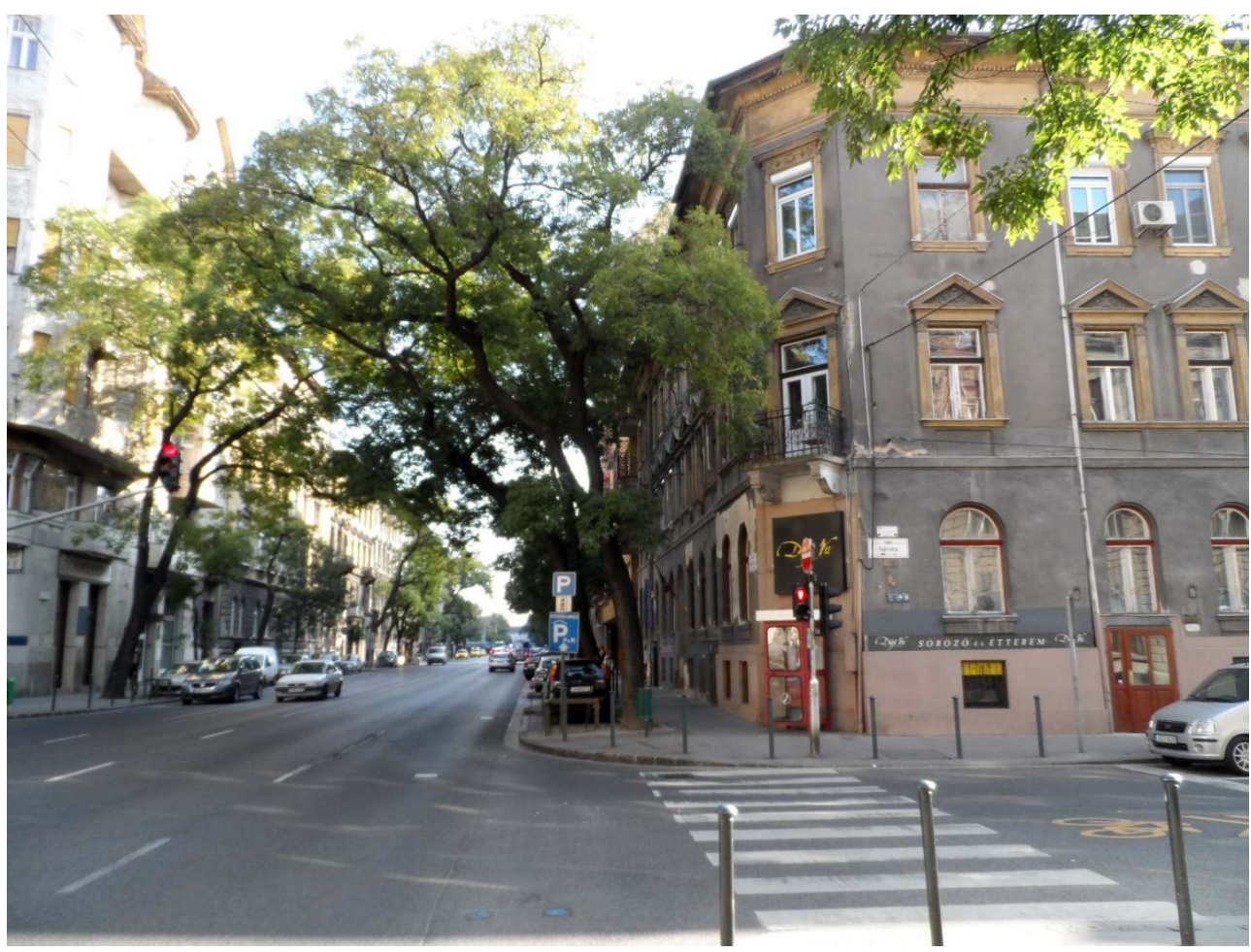

(SOURCE: PHOTOgRAPH TAKEN BY THE AUTHORS)

\section{Conclusions}

In this paper, a concise overview of the transformation of Budapest's city center and its close proximity has been provided, spanning from the early history of the area to the emergence of today's new economy. Building on the tradition of European urban geography, the notion of 'city' was adapted to describe centrally located and economically dynamic urban areas with constantly fluctuating boundaries. Since the very beginning of the 1990s, the 'city' of Budapest is characterized by persistent growth, transformation and economic expansion, currently concentrating a wide variety of tertiary (and quaternary) functions that were completely absent during the decades of state socialism.

After delineating the capital's 'economic city', the impacts of the new economy on urban morphology were presented based on the results of an empirical study. Our investigation revealed that the companies associated with the new economy are primarily concentrated in (and around) the city center, constituting a number of new economy clusters. Since the majority of these clusters are also located in the capital's easily accessible inner areas, we assume that the emergence of the new economy predominantly affects the 'city' of Budapest.

In addition, in the international urban geography literature there is a growing interest towards the issue of urban transformation (and gentrification) driven by the new economy. Therefore, by means of on-site examinations, we also attempted to shed light on the relationship between the spatial concentration of new economy firms and the 
processes of urban renewal. As a result, we observed significant urban transformation (i.e. the construction of office blocks or apartment complexes) in the case of most new economy clusters, even though it is depending more on their location within the capital city than on the quality of their original property stock.

In summary, the 'city' of Budapest is in a constant change and transformation from the beginning of the $20^{\text {th }}$ century, apart from the socialist era. Most economic innovations and changes are manifested in this area for the first time, including the recent emergence of the new economy. Nonetheless, these transformation processes are significantly slower here compared to those experienced in several North American metropolises; consequently, post-socialist Budapest is not yet characterized by a comprehensive new economy driven urban transformation or renewal, although initial signs of this process are already apparent in some of the capital's 'city' areas.

\section{BIBLIOGRAPHY}

Baji, Péter. 2012. A gazdasági city értelmezése és határai Budapesten [Conceptualizing and Delineating the ‘Economic City’ in Budapest]. Településföldrajzi Tanulmányok 1: 101-114.

Baji, Péter. 2014. Az új gazdaság értelmezése a városi tér léptékeiben [Conceptualizing the New Economy on Different Urban Scales]. En Tér-rétegek: Tanulmányok a XXI. század térfordulatairól [Layers of Space: Studies on the Spatial Turns of the $21^{\text {st }}$ Century], compilado por Dúll, Andrea y Izsák, Éva, pp. 134-158. Budapest: L'Harmattan.

Barnes, Trevor y Hutton, Thomas. 2009. Situating the New Economy: Contingencies of Regeneration and Dislocation in Vancouver's Inner City. Urban Studies 46: 1249-1271.

Beluszky, Pál. 1992. Budapest és a modernizáció kihívásai [Budapest and the Challenges of Modernization]. Tér és Társadalom, 6(3-4): 15-54.

Berényi, István. 1994. Changes in the Social and Regional Structures of Budapest 1970-1990. Acta Geographica Lovaniensia, 34: 463-468.

Brunotte, Ernst, Gebhardt, Hans, Meurer, Manfred, Meusburger, Peter y Nipper, Josef. 2001. Lexikon der Geographie in vier Bänden. 1. Band [Encyclopedia of Geography in Four Volumes. Volume 1]. Berlin/Heidelberg: Spektrum Akademischer Verlag.

Bulla, Béla y Mendöl, Tibor. 1947. A Kárpát-medence földrajza [Geography of the Carpathian Basin]. Budapest: Egyetemi Nyomda.

Burdack, Joachim y Herfert, Günter. (1998). Neue Entwicklungen an der Peripherie europäischer Großstädte [New Developments on the Periphery of European Metropolises]. Europa Regional, 6(2): 26-44.

Catungal, John Paul, Leslie, Deborah y Hii, Yvonne. 2009. Geographies of Displacement in the Creative City: The Case of Liberty Village, Toronto. Urban Studies, 46: 1095-1114.

Dear, Michael y Flusty, Steven. 2002. The Spaces of Postmodernity. Oxford: Blackwell. 
Egedy, Tamás y Kovács, Zoltán. 2011. Budapest as a Destination of Migration: The View of Transnational Creative Workers. Hungarian Geographical Bulletin, 60(2): 161-188.

Enyedi, György. 1999. Budapest: Gateway zum südöstlichen Europa [Budapest: Gateway to Southeast Europe]. Geographische Rundschau, 51(10): 542-547.

Enyedi, György. 2002. A városok kulturális gazdasága [Cultural Economy of Cities]. Földrajzi Értesíto", 51(1-2): 19-29.

Faßmann, Heinz. 1999. Regionale Transformationsforschung: Konzeption und empirische Befunde [Regional Transformation Research: Concepts and Empirical Results]. En Ostmitteleuropa im Umbruch: Wirtschafts- und sozialgeographische Aspekte der Transformation [East Central Europe in Transition: Economic and Social Geographical Aspects of the Transformation] compilado por Pütz, Robert, pp. 11-20. Mainz: Mainzer Kontaktstudium Geographie.

Faßmann, Heinz y Lichtenberger, Elisabeth. 1995. Märkte in Bewegung: Metropolen und Regionen in Ostmitteleuropa [Markets is Motion: Metropolises and Regions in East Central Europe]. Wien: Böhlau Verlag.

Florida, Richard. 2005. Cities and the Creative Class. New York/London: Routledge.

Goldhaber, Michael H. 1997. Attention Shoppers! The Currency of the New Economy Won't Be Money, but Attention. A Radical Theory of Value. Wired Magazine, 12: 182-190.

Haltenberger, Mihály. 1942. Budapest városföldrajza [Urban Geography of Budapest]. Budapest: Stephaneum Nyomda.

Heineberg, Heinz. 2001. Grundriss Allgemeine Geographie: Stadtgeographie [Outlining General Geography: Urban Geography]. Paderborn: Schöningh.

Helbrecht, Ilse. 1998. The Creative Metropolis: Services, Symbols and Spaces. International Journal of Architectural Theory, 3(1).

Hutton, Thomas A. 2008. The New Economy of the Inner City: Restructuring, Regeneration and Dislocation in the $21^{\text {st }}$ Century Metropolis. London/New York: Routledge.

Indergaard, Michael. 2009. What to Make of New York's New Economy? The Politics of the Creative Field. Urban Studies, 46: 1063-1093.

Izsák, Éva y Probáld, Ferenc. 2001. Recent Differentiation Processes in Budapest's Suburban Belt. En Transformations in Hungary: Essays in Economy and Society compilado por Meusburger, Peter y Jöns, Heike, pp. 291-316. Heidelberg: Physica Verlag.

Izsák, Éva y Schulz, Marlies. 2006. Cityfunktionen im Wandel: Berlin und Budapest [Changing City Functions: Berlin and Budapest]. Berlin: Berliner Geographische Arbeiten, Humboldt Universität zu Berlin.

Jakobi, Ákos. 2007. Hagyományos és új területi különbségek az információs társadalomban [Traditional and New Spatial Disparities in Information Society] (PhD Thesis). Eötvös Loránd University, Budapest.

Jungmann, Walter-Wilhelm y Szöcs, Andreas. 2001. Wien-Budapest: Die mitteleuropäischen DonauMetropolen zwischen Tradition und Moderne [Vienna-Budapest: Central European Danube Metropolises between Tradition and Modernity], pp. 8-53. Marburg: Marburger Geographische Gesellschaft.

Keim, Karl-Dieter. 2000. Statement zur Plenumdiskussion 'Perspektiven zukünftiger Transformationsforschung' [Statement for Plenary Discussion 'Perspectives for Future Transformation Research']. Europa Regional, 8(3-4): 52-53. 
Kluczka, Georg. 1996. Cityfunktionen von Budapest im Wandel [Changing City Functions of Budapest]. Berliner Geographie Studien, 44: 141-155.

Kovács, Zoltán. 1992. A budapesti bérlakásszektor privatizációjának társadalmi és városszerkezeti hatásai [Social and Spatial Impacts of the Privatization of State Housing in Budapest]. Tér és Társadalom, 6(3-4): 55-73.

Kovács, Zoltán. 1993. A társadalmi-gazdasági átalakulás hatása Budapest városfejlődésére [The Impact of Socio-Economic Transformation on the Urban Development of Budapest]. Földrajzi Értesíto", 42(1-4): 41-49.

Kovács, Zoltán. 2005. Budapest funkcionális átalakulásának főbb vonásai a rendszerváltozás után [Main Features of the Functional Transformation of Budapest during the Politico-Economic Transition]. Földrajzi Közlemények, 53(1-2): 83-102.

Kovács, Zoltán y Wießner Reinhard. 1995. Die Umgestaltung des Budapester Wohnungsmarktes unter dem Einfluss von Marktwirtschaft und Wohnungspolitik [Transformation of the Housing Market of Budapest under the Influence of Market Economy and Housing Policy]. En Vom Plan zum Markt: Eine Untersuchung am Beispiel Ungarns [From Plan to Market: A Study on the Example of Hungary] Meusburger, Peter y Klinger, Andras, pp. 229-248. Heidelberg: Physica Verlag.

Kovács, Zoltán y Wießner Reinhard. 1997. Processe und Perspektiven der Stadtentwicklung in Ostmittleuropa [Processes and Perspectives of Urban Development in East Central Europe]. Passau: LIS Verlag.

Kovács, Zoltán y Wießner Reinhard. 1999. Stadt- und Wohnungsmarktentwicklung in Budapest: Zur Entwicklung der innerstädtischen Wohnquartiere in Transformationsprozess [Urban and Housing Market Development in Budapest: On the Development of Inner City Residential Areas during the Process of Transformation]. Leipzig: Institut für Länderkunde.

Lichtenberger, Elisabeth. 1978. Stadtgeographische Führer Wien [Urban Geographical Guide for Vienna]. Wien: Borntraeger.

Lichtenberger, Elisabeth. 1995. Die Entwicklung der Innenstadt von Budapest zwischen City- und Slumbildung [Development of the Inner City of Budapest between 'City' and Slum Formation]. Erdkunde, 49(2): 138-151.

Lichtenberger, Elisabeth, Cséfalvay, Zoltán y Paal, Michaela. (1995). Várospusztulás és felújítás Budapesten [Urban Decay and Revitalization in Budapest]. Budapest: Magyar Trendkutató Központ.

Online Etymology Dictionary (n.d.). Retrieved 17 June 2015, from the OED website: http:// www.etymonline.com/index.php?allowed_in_frame=0\&search=city\&searchmode=none

Park, Robert. E. y Burgess, Ernest W. 1925. The City. Chicago: University of Chicago Press.

Sacco, Pierluigi y Blessi, Giorgio Tavano. 2009. The Social Viability of Culture-Led Urban Transformation Processes: Evidence from the Bicocca District, Milan. Urban Studies, 46: 11151135.

Scott, Alan J. (1997). The Cultural Economy of Cities. International Journal for Urban and Regional Research, 21: 321-339.

Stadelbauer, Jörg. 2000. Räumliche Transformationsprozesse und Aufgaben geographischer Transformationsforschung [Spatial Transformation Processes and Challenges for Geographical Transformation Research]. Europa Regional, 8(3-4): 60-71. 
Sýkora, Ludek. 2009. Post-Socialist Cities. En International Encyclopedia of Human Geography (Volume 8) compilado por Kitchin, Rob y Thrift, Nigel, pp. 387-395. Oxford: Elsevier.

Szabó, Katalin y Hámori, Balázs. 2006. Információgazdaság [Information Economy]. Budapest: Akadémiai Kiadó.

Tietze, Wolf. 1968. Westermann Lexikon der Geographie [Westermann Lexicon of Geography]. Braunschweig: Georg Westermann Verlag.

Waitt, Gordon y Gibson, Chris. 2009. Creative Small Cities: Rethinking the Creative Economy in Place. Urban Studies, 46: 1223-1246.

Zheng, Jane. 2011. 'Creative Industry Clusters' and the 'Entrepreneurial City' of Shanghai. Urban Studies, 48: 3561-3582.

\section{ABSTRACTS}

Within the confines of this paper, we aim at exploring some of the recent transformation processes of the city center of Budapest. First, a concise overview of the geographical notion of 'city' is provided, after which the historical formation, evolution and transformation of Budapest's economic center is presented. Second, the intricate relationship between the new economy and city centers is outlined, followed by the presentation of the results of an empirical research focusing on the emergence and the spatiality of the new economy in the Hungarian capital's city center. Based on the findings of the research, we argue that in Budapest, just as in other European metropolises, the first apparent signs of economic changes are manifested in the 'city', and they diffuse from these central areas to other (inner) parts of the city.

En los límites de este artículo, queremos explorar algunos de los recientes procesos de mutación del centro de la ciudad de Budapest. Haremos inicialmente un breve panorama de la noción geográfica de "ciudad" a fin de presentar la formación, evolución y trasformación histórica del centro económico de Budapest. En segundo lugar, destacaremos la intrincada relación entre la nueva economía y el centro de la ciudad, seguida de una exposición de los resultados de una investigación empírica enfatizando la emergencia y la espacialidad de aquella nueva economía en la ciudad en pantalla. Por último, argumentamos que los primeros signos aparentes de cambios económicos se manifiestan en la "ciudad" y se difunden de sus áreas centrales a otras partes más empobrecidas cercanas al centro.

Dans les limites de cet article, on va examiner quelques processus récents de transformation du centre de la ville de Budapest. Pour cela, on commence pour présenter la formation, l'évolution et le changement historique du centre économique de Budapeste. On montre ensuite le rapport complexe entre la nouvelle économie et le centre ville, à la suite de notre recherche empirique dont les résultats soulignent l'espacialité de cette nouvelle économie à Budapest. Finalement, on peut conclure que les premiers signes visibles de changements économiques se manifestent dans la « ville » et se répandre à partir des aires centraux de la ville vers des autres parties proches du centre ville les plus appauvries.

Nos limites desse artigo, queremos explorar alguns dos recentes processos de mutação do centro da cidade de Budapeste. Para tanto, faremos inicialmente um breve panorama da noção geográfica de "cidade" a fim de apresentar a formação, evolução e tranformação histórica do centro econômico de Budapeste. Em segundo lugar, destacaremos a intrincada relação entre a nova economia e o centro da cidade, seguida de uma exposição dos resultados de uma pesquisa empírica enfatizando a emergência e a espacialidade daquela nova economia na cidade em tela. 
Por fim, argumentamos que os primeiros sinais aparentes de mudanças econômicas manifestamse na "cidade" e difundem-se de suas áreas centrais para outras partes mais empobrecidas próximas ao centro.

INDEX

Mots-clés: transformation urbaine, développement historique, centre ville, nouvelle économie, Budapest

Palavras-chave: transformação urbana, desenvolvimento histórico, centro da cidade, nova economia, Budapeste

Keywords: urban transformation, historical development, city center, new economy, Budapest Palabras claves: transformación urbana, desarrollo histórico, centro de la ciudad, nueva economía, Budapest

\section{AUTHORS}

\section{PÉTER BAJI}

Hungarian Academy of Sciences (MTA), Centre for Social Sciences, Institute for Sociology. Email: bajipeti.bcs@gmail.com

\section{MÁRTON BERKI}

Eötvös Loránd University (ELTE), Department of Social and Economic Geography. Email: berkimarton@yahoo.com

\section{ÉVA IZSÁK}

Eötvös Loránd University (ELTE), Department of Regional Science. Email: eva.izsak@gmail.com 